\title{
MODEL TRANSFORMATIONAL SERVICE DENGAN PENDEKATAN TEORI SISTEM INTERPERSONAL IMOGENE KING TERHADAP MUTU PELAYANAN KESEHATAN DIPUSKESMAS TANJUNG PALAS KABUPATEN BULUNGAN KALIMANTAN UTARA TAHUN 2018
}

\author{
Indah Nursanti ${ }^{1}$, Muhammad Hadi ${ }^{2}$, Rochadi Haryanto ${ }^{3}$ \\ ${ }_{1,2,3}^{1}$ Universitas Muhammadiyah Jakarta, Fakultas Ilmu Keperawatan \\ Diterima : 8 November 2018 Disetujui : 15 November 2018 \\ Email : bxn.indah@yahoo.com
}

\begin{abstract}
Abstrack
Background : There are issues that Health Center is still considered as a middle to lower health service, unsatisfactory service, and the attitude of officers who arbitrarily provide services that cause the Health Center got a bad view. Observations on 5 nurses were still found the nurses who were still passive towards work, rarely smiled, and did not care about their appearance. Transformational service as a service at the highest level that is expected to be able to change customer character because it is able to provide solutions to customer problems. Purpose: The purpose of this study was to know the Transformational Service with Imogene King interpersonal system approach and the effect to the quality of health service at Tanjung palas Health Center, Bulungan District, North Kalimantan in 2018 2018. Method: This was a quantitative study with a quasi-experimental research method with pre-post and control group design. The sample of this study were patients at Tanjung Palas Health Center and Bumi Rahayu Health Center, with total sample in the intervention group were 40 respondents and in the control group were 40 respondents, used a simple random sampling technique and analysis method of General Linear Model Repeated Measure (GLM-RM). Result: The results of this study showed that there were significant figures at the level of health services at Tanjung Palas Health Center. The mean values from measurement 1 to 4 were 76.20 from measurements 1 and $d 88.29$ in measurement 4 with a difference of 12.09. While the average value in the control group between measurements 1 and 4 were 75.93 and 83.44 with a difference of 07.51. From the difference in the average value between the differences in quality of health services in measurements 1 and 4 in the intervention group compared to the control group made conclusion that Ha accepted. Conclusion: The Transformational Service model with Imogene King interpersonal system approach was effective to improve the quality of health service at Tanjung palas Health Center, Bulungan District, North Kalimantan in 2018. Conclusion : The Transformational Service model with Imogene King interpersonal system approach was effective to improve the quality of health service at Tanjung palas Health Center, Bulungan District, North Kalimantan in 2018.
\end{abstract}

Keywords : Transformational Service, System Interpersonal Imogene King, and Quality of Health Service 


\section{PENDAHULUAN}

Gambaran pencapaian tahap kualitas pelayanan kesehatan Puskesmas hingga saat ini juga disebabkan faktor sikap dan kinerja personal yang meliputi faktor internal dan ekternal. Adanya isu bahwa Puskesmas masih dianggap sebagai pelayanan kesehatan menengah kebawah, pelayanan yang kadang kurang memuaskan, sikap petugas yang seenaknya dalam memberikan pelayanan yang menyebabkan kadang Puskesmas mendapatkan pandangan yang buruk. Hal tersebut mengindikasikan bahwa personil kesehatan atau provider kesehatan dalam sebuah organisasi merupakan fokus daripada hasil karya organisasi tersebut. Artinya, bahwa personil kesehatan/provider kesehatan harus mempunyai ciri dan sifat yang melekat pada dirinya. Menurut Parasuraman dalam Muninjaya (2015) pelayanan yang dimaksud tersebut antara lain adalah kemampuan dalam hal tampilan fisik (tangibles), kemampuan untuk memberikan pelayanan yang dapat diandalkan dan akurat (realibility), kemauan untuk membantu para pelanggan dan memberikan pelayanan dengan sebaik mungkin (responsiveness), pengetahuan dan kebaikan karyawan untuk memberikan kepercayaan dan kayakinan (assurance) serta kepedulian dan perhatian terhadap pelanggannya secara individu (empathy).

Transformational service sebagai servis pada tingkatan tertinggi diharapkan mampu mengubah karakter pelanggan karena mampu memberikan solusi atas masalah pelanggan. Bukan hanya memunculkan perasaan Exciting saja sebagai tujuannya, namun lebih dari
Transformational service yang ingin menghadirkan kesadaran dalam diri pelanggan.

Beberapa penelitian memberikan gambaran tentang mutu pelayanan di Puskesmas (Widi Utami, 2012) menunjukkan bahwa kualitas pelayanan yaitu pelayanan, kemampuan petugas, biaya kesehatan, tersedianya obat-obatan, dan keamanan lingkungan secara parsial dan stimulan berpengaruh terhadap kepuasan pasien. Penelitian Rustam Effendi (2013) menunjukkan bahwa responden yang menyatakan mendapat kenyamanan cukup sebanyak 94\% sedangkan sisanya responden yang kurang nyaman sebanyak $6 \%$.

Hasil observasi pada 5 orang perawat tersebut bahwa masih ditemukan perawat yang masih bersikap pasif terhadap pekerjaan, jarang senyum, dan masih tidak peduli dengan penampilannya. Penguasaan kompetensi yang baik pada servis terhadap pelayanan harus di tanamkan dan menjadi unsur yang melekat pada perawat sehingga setiap tindakan atau asuhan yang diberikan bukan hanya terselesainya pekerjaan tapi juga menghasilkan mutu pelayanan yang baik. Tidak semua pasien bisa memahami perawat sedang sibuk, fasilitas pelayanan yang kurang, tenaga yang kurang,perawat yang tidak ramah,penampilan yang tidak menarik,pekerjaan yang menumpuk sehingga perawat tidak bisa memberikan pelayanan yang optimal. Pasien membutuhkan respon yang cepat dalam setiap keluhan nya ,terlebih Puskesmas selama ini masih dianggap sebagai pilihan kunjungan kedua apabila ada rumah sakit dalam satu wilayah.

Berdasarkan uraian permasalahan terkait dengan mutu pelayanan di Puskesmas Tanjung Palas Kabupaten 
Bulungan, masih kurangnya penerapan servis pelayanan yang menggunakan model keperawatan, serta keluhan pasien tentang pelayanan yang diberikan seperti petugas perawat dirasakan kurang perhatian terhadap keluhan pasien, kurang tanggap terhadap keluhan yang di rasakan pasien, penampilan yang belum rapi, serta komunikasi yang kurang edukatif serta hasil observasi masih ditemukan perawat yang masih bersikap pasif terhadap pekerjaan, jarang senyum, dan masih tidak peduli dengan penampilannya.

Dengan penjelasan tersebut maka permasalahan maka Penerapan Model Tranformational service dengan pendekatan sistem interpersonal Imogene King efektif diberikan sebagai alternatif untuk meningkatkan mutu pelayanan di Puskesmas Tanjung Palas Kabupaten Bulungan.

\section{METODE PENELITIAN}

Penelitian ini menggunakan pendekatan kuantitatif dengan metode penelitian quasi eksperimental Jenis penelitian adalah quasi eksperimen dengan rancangan pre post with control group design. Total 80 responden ikut serta dalam penelitian ini. Kemudian dibagi menjadi 2, kelompok intervensi dan kelompok kontrol. Menggunakan pengukuran GLMRM, dan dilaksanakan selama 4 minggu.

Kepada masing-masing kelompok diminta tanggapan tentang mutu pelayanan menggunakan kuesioner. Untuk kelompok intervensi terlebih dahulu dilakukan pengukuran 1 , setelah diperoleh hasilnya kemudian diterapkan Transformational service dengan pendekatan sistem interpersonal Imogene King . sedangkan kelompok kontrol tidak mendapat perlakuan. Penerapan ini dilaksanakan selama 4 minggu dan setiap 1 minggu dilakukan pengukuran akhir untuk masing-masing kelompok dan disimpulkan apakah terdapat perbedaan mutu pelayanan kesehatan antara kelompok intervensi dan kelompok kontrol.

Data diolah menggunakan komputer. Kaji etik dilakukan oleh Komite Etik Riset Fakultas Ilmu Keperawatan Universitas Muhammadiyah Jakarta

\section{HASIL PENELITIAN}

Tabel 1. Distribusi Frequensi Responden pada kelompok intervensi dan kelompok kontrol menurut umur, jenis kelamin dan tingkat pendidikan.

\begin{tabular}{lcccccc}
\hline Variabel & F & $\begin{array}{c}\text { Kelompok } \\
\text { Intervensi } \\
\text { Presentase }\end{array}$ & F & $\begin{array}{c}\text { Kelompok } \\
\text { Kontrol } \\
\text { Presentase }\end{array}$ & F & Presentase \\
$\quad$ Umur & & & & & & \\
1. $\quad$ 18 th & 5 & 14,6 & 4 & 9,8 & 9 & 11,25 \\
2. $18-25$ th & 7 & 17,1 & 10 & 24,4 & 17 & 21,25 \\
3. $26-35$ th & 12 & 29,3 & 14 & 34,1 & 26 & 32,5 \\
4. $36-45$ th & 8 & 19,5 & 6 & 17,1 & 14 & 17,5 \\
$5.46-55$ th & 6 & 14,6 & 4 & 9,8 & 10 & 12,5 \\
6. $>55$ th & 2 & 4,9 & 2 & 4,9 & 4 & 5 \\
\hline
\end{tabular}




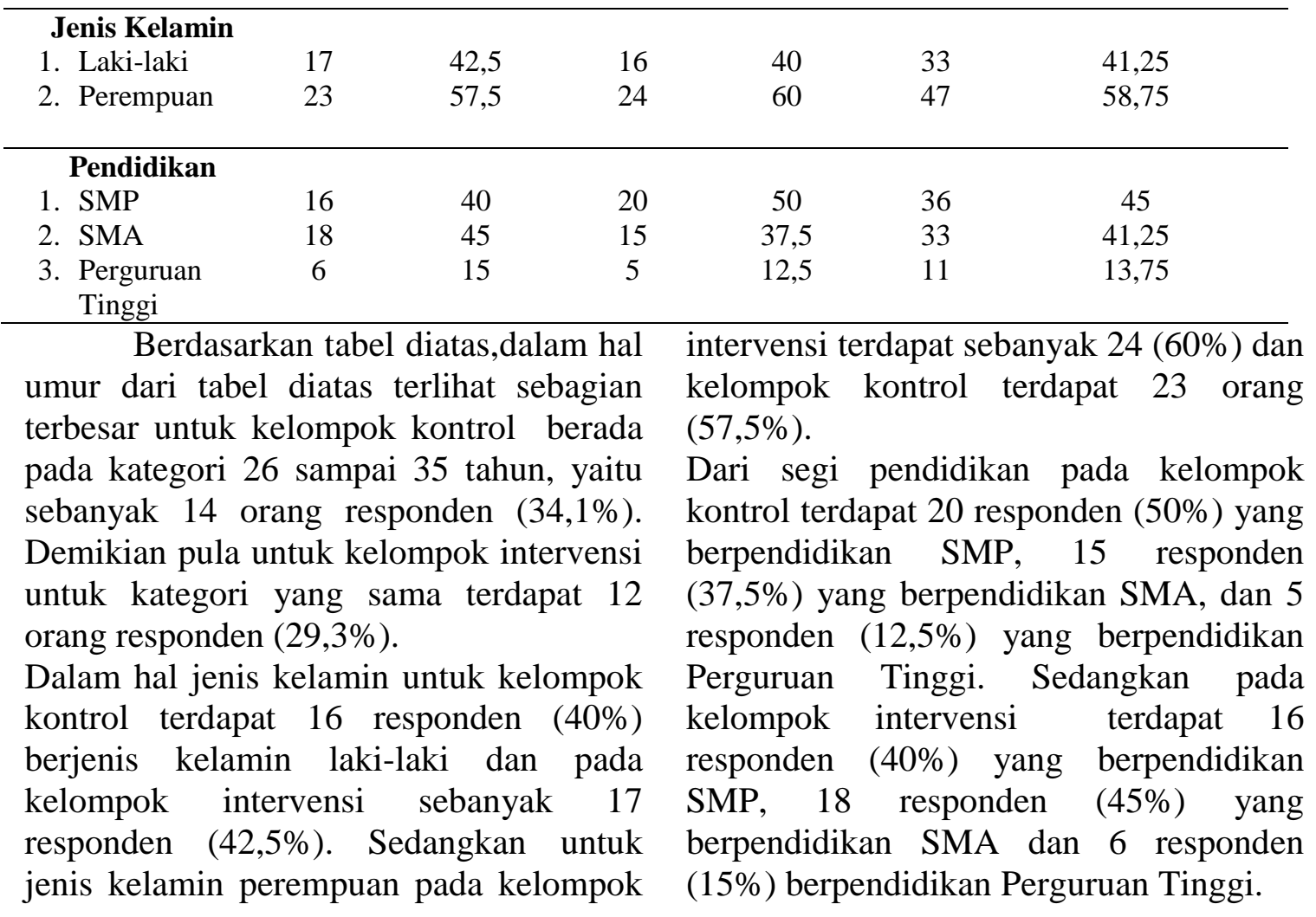

Tabel 2. Rata-rata (Mean), SD dan Min-Maks Mutu Pelayanan kesehatan kelompok kontrol dan kelompok intervensi berdasarkan pengukuran 1 sampai 4.

\begin{tabular}{lcccccc}
\hline $\begin{array}{c}\text { Variabel } \\
\text { Kontrol }\end{array}$ & Mean & N & SD & SE & Min-maks & 95\% CI \\
1. Pengukuran 1 & 75,93 & 10 & 4,150 & 0,648 & $65-85$ & $74,62-77,24$ \\
2. Pengukuran 2 & 78,41 & 10 & 3,860 & 0,603 & $67-86$ & $77,20-79,63$ \\
3. Pengukuran 3 & 80,85 & 10 & 3,403 & 0,531 & $71-88$ & $79,78-81,93$ \\
4. Pengukuran 4 & 83,44 & 10 & 2,958 & 0,462 & $76-90$ & $82,51-84,37$ \\
& & & & & & \\
\hline & & & & & & \\
1. Pengukuran 1 & 76,20 & 10 & 4,760 & 0,743 & $65-86$ & $74,69-77,70$ \\
2. Pengukuran 2 & 79,59 & 10 & 4,466 & 0,698 & $68-87$ & $78,18-81,00$ \\
3. Pengukuran 3 & 89,24 & 10 & 4,928 & 0,770 & $76-99$ & $82,69-85,80$ \\
4. Pengukuran 4 & 88,29 & 10 & 5,419 & 0,846 & $78-109$ & $86,58-90,00$ \\
& & & & & & \\
\hline
\end{tabular}

Berdasarkan table 2 tersebut diatas mutu pelayanan kesehatan pada kelompok intervensi maupun kontrol trend perkembangannya positif. Artinya, dari hasil pengukuran yang dilakukan secara berulang-ulang terbukti mutu pelayanan di kedua kelompok terjadi peningkatan. Hal ini dapat dilihat pada nilai mean pada setiap pengukuran mulai dari pengukuran pertama sampai pengukuran ke empat. 
Tabel 3. Rata-rata (Mean), SD dan Min-Maks Mutu Pelayanan Kesehatan pada kelompok intervensi dan kelompok kontrol pada Pengukuran 1 dan 4.

\begin{tabular}{ccccccccc}
\hline Variabel & Mean & N & SD & SE & $\begin{array}{c}\text { Min- } \\
\text { maks }\end{array}$ & $\mathbf{9 5 \%}$ CI & $\begin{array}{c}\text { Mean } \\
\text { dif }\end{array}$ & $\begin{array}{c}\text { p- } \\
\text { Value }\end{array}$ \\
$\begin{array}{c}\text { Intervensi } \\
\text { Pengukuran 1 }\end{array}$ & 76,20 & 10 & 4,760 & 0,743 & $65-86$ & $74,69-77,70$ & 21,50 & 0,000 \\
Pengukuran 4 & 88,29 & 10 & 5,419 & 0,846 & $78-109$ & $86,58-90,00$ & & 0,000 \\
Kontrol & & & & & & & & \\
$\begin{array}{c}\text { Pengukuran 1 } \\
\text { Pengukuran 4 }\end{array}$ & 75,93 & 10 & 4,150 & 0,648 & $65-85$ & $74,62-77,24$ & 20,50 & 0.000 \\
& 83,44 & 10 & 2,958 & 0,462 & $76-90$ & $82,51-84,37$ & & 0,000 \\
\hline
\end{tabular}

Rata-rata Mutu Pelayanan Kesehatan pada kelompok intervensi dan kelompok kontrol antara pengukuran 1 dan setelah intervensi atau pengukuran 4 diterapkan Model Transformational Service dengan sistem interpersonal Imogene King khusus untuk pengukuran seperti tergambar dalam tabel 5.3 dibawah.

Hasil analisis diatas menunjukkan bahwa terdapat perbedaan nilai rata-rata mutu pelayanan kesehatan di Puskesmas Tanjung Palas sebagai kelompok intervensi antara sebelum intervensi dan setelah intervensi. Dalam pengukuran 1 atau sebelum intervensi nilai mean 76,20 dengan standar deviasi 4,76 dan setelah intervensi nilai mean 88,29 dengan standar deviasi 5,419.

Hasil estimasi confident interval dapat disimpulkan bahwa untuk 95\% CI diyakini mutu pelayanan kesehatan pada pengukuran ke 1 pada kelompok intervensi adalah antara 74,62 - 77,70 dan hasil estimasi confident interval mutu pelayanan kesehatan pada pengukuran ke
4 adalah 86,58 - 90,00. Hasil analisis tersebut menunjukkan bahwa rata-rata mutu pelayanan kesehatan pada kelompok intervensi memiliki proporsi yang berbeda antara pengukuran 1 dan pengukuran 4 , dengan nilai Delta 21,50 dan $p$-Value 0,000

Sedangkan hasil analisis nilai ratarata mutu pelayanan kesehatan di Puskesmas Bumi Rahayu sebagai kelompok kontrol pada pengukuran 1 adalah 75,93 dengan standar deviasi 4,150 dan rata-rata pada pengukuran 4 adalah 83,44 dengan standar deviasi 2,958. Hasil estimasi confident interval untuk 95\% CI diyakini mutu pelayanan kesehatan pada pengukuran 1 pada kelompok kontrol adalah antara 74,62 sampai dengan 77,24 dan estimasi interval pada mutu pelayanan kesehatan pada pengukuran ke 4 adalah 82,51 sampai dengan 84,37, nilai Delta 20,50 dengan $p$-Value 0,000. Hasil analisis tersebut menujukkan bahwa distribusi mutu pelayanan rata-rata responden pada kelompok kontrol memiliki proporsi yang berbeda. 
Tabel 4. Mutu pelayanan kesehatan pada Kelompok Intervensi dan Kelompok Kontrol dari hasil Pengukuran 1 dan Pengukuran 4.

\begin{tabular}{|c|c|c|c|c|}
\hline Variabel & Mean & $\mathbf{N}$ & SD & p-Value \\
\hline \multicolumn{5}{|l|}{ Intervensi } \\
\hline 1. Pengukuran 1 & & & & \\
\hline 2. Pengukuran 4 & 76,20 & 10 & 2,450 & 0,000 \\
\hline 3. Kenaikan & $\begin{array}{l}88,29 \\
12,09\end{array}$ & 10 & 5,633 & \\
\hline Kontrol & & & & \\
\hline 1. Pengukuran 1 & & & & \\
\hline 2. Pengukuran 4 & 75,93 & 10 & 0,978 & 0,000 \\
\hline 3. Kenaikan & $\begin{array}{l}83,44 \\
07,51\end{array}$ & 10 & 1,551 & \\
\hline
\end{tabular}

Hasil analisis diatas menunjukkan bahwa nilai rata-rata mutu pelayanan kesehatan pada kelompok intervensi pada pengukuran 1 adalah 76,20 dengan standar deviasi 2,450 dan nilai rata-rata mutu pelayanan kesehatan setelah intervensi atau pengukuran 4 adalah 88,29 dengan standar deviasi 5,633. Terjadi kenaikan rata-rata skore mutu pelayanan sebesar 12,09 .

Hasil uji statistik perbedaan kedua nilai rata-rata (mean) pada kelompok intervensi didapatkan nilai $p$ value sebesar 0,000 , sehingga dapat disimpulkan bahwa ada perbedaan yang signifikan dalam hal mutu pelayanan bagi responden antara sebelum dan setelah intervensi.
Sedangkan nilai rata-rata mutu pelayanan kesehatan pada kelompok kontrol pada pengukuran 1 diperoleh nilai rata-rata atau mean sebesar 75,93 dengan standar deviasi 0,978. Sedangkan pada pengukuran 4 diperoleh mean 83,44 dengan standar deviasi 1,551. Hasil uji statistik didapatkan nilai $p$ value sebesar 0,000 sehingga dapat disimpukan bahwa ada perbedaan yang signifikan antara mutu pelayanan pada kelompok kontrol antara pre test dan pos test. Dengan demikian juga terjadi peningkatan sebesar 7.51. Namun demikian besarnya nilai perbedaan antara pre dan post test di Puskemas kontrol tidak sebesar di Puskesmas kelompok intervensi.

Tabel 5. Uji Normalitas data mutu pelayanan kesehatan pada kelompok intervensi dan kelompok kontrol.

\begin{tabular}{lcccc}
\hline Kelompok & $\begin{array}{c}\text { Variabel } \\
\text { Intervensi }\end{array}$ & Z-Value & P-Value & Kesimpulan \\
& -.Pengukuran 1 & & & \\
& -.Pengukuran 2 & 1,161 & 0,135 & Normal \\
& -.Pengukuran 3 & 0,622 & 0,834 & Normal \\
& & 0,969 & 0,304 & Normal \\
& & 1,113 & 0,168 & Normal \\
\hline Kontrol & -. Pengukuran 1 & 1,230 & 0,097 & Normal \\
\hline
\end{tabular}




$\begin{array}{llll}\text {-. Pengukuran 2 } & 1,366 & 0,048 & \text { Normal } \\ \text { - Pengukuran 3 } & 1,162 & 0,134 & \text { Normal } \\ \text {-. Pengukuran 4 } & 1,262 & 0,083 & \text { Normal }\end{array}$

Tehnik yang dilakukan peneliti untuk menguji normalitas adalah menggunakan Kolmogorov-Semirnov pada semua pengukuran kelompok intervensi maupun kontrol. menunjukkan hasil uji normalitas distribusi data kelompok intervensi dan kontrol menunjukkan keadaan normal, karena $p$-Value $>0,05$. walaupun pada pengukuran 2 untuk kelompok kontrol p-Value 0,048 atau sedikit $<0,05$, akan tetapi nilai tersebut bisa diabaikan. Jadi dapat disimpulkan bahwa kedelapan pengukuran mutu pelayanan kesehatan di kedua kelompok berdistribusi normal.

Tabel 6. Uji Sperisitas pada kelompok intervensi dan kelompok kontrol

\begin{tabular}{ccc}
\hline Kelompok & $\begin{array}{c}\text { Greenhouse- } \\
\text { Geisser }\end{array}$ & $\mathrm{F}$ \\
\hline Intervensi & 1,708 & 286,573 \\
Kontrol & 1,708 & 17,192
\end{tabular}

Uji sphericity menggunakan uji Mauchly dengan nilai $p=$ Value $<0,05$

( $p$ value $=0,000)$, maka data tidak memenuhi syarat sperisitas sehingga peneliti menggunakan nilai koreksi Greenhouse-Geisser 1,708, dan dapat disimpulkan bahwa uji Sphericity dapat terpenuhi dan data proporsional.

Untuk mengetahui perkembangan efektifitas dari waktu ke waktu dari penerapan model Transformational Service dengan sistem interpersonal Imogene King peneliti menggunakan metode analisis General Linier Model-

\section{Repeated Measure}

Gambar 1. Metode Analisis General Linier Model-Repeated Measure

Dapat dilihat trend perubahan untuk kelompok intervensi yang terus

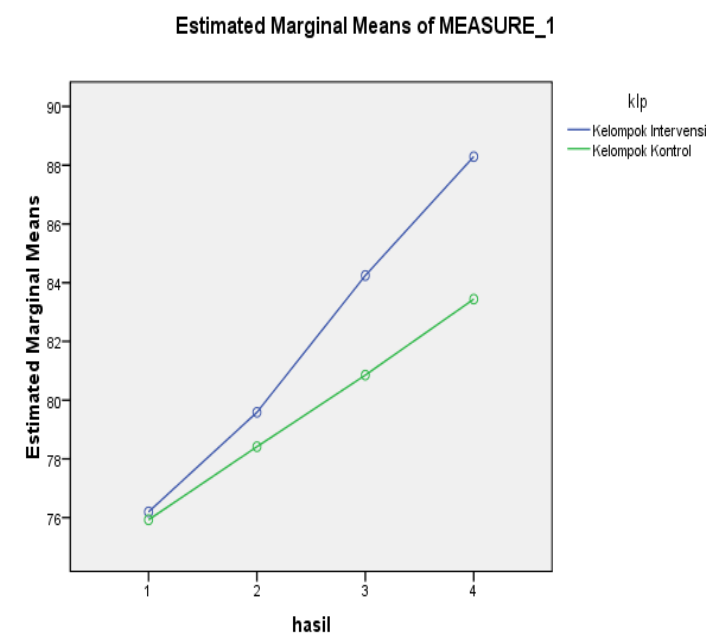

meningkat mulai dari pengukuran 2 sampai pengukuran 4. Akan tetapi perubahan tersebut dalam upaya meningkatkan mutu pelayanan belum mencapai titik optimum.

\section{PEMBAHASAN}

Berdasarkan hasil penelitian didapatkan bahwa model Transformational Service dengan Pendekatan sistem interpersonal Imogene King dan pengaruhnya terhadap mutu pelayanan kesehatan yang diberikan pada kelompok intervensi mempunyai pengaruh yang sangat kuat yang tergambar pada pengukuran 1, pengukuran 2 , pengukuran 3 dan 
pengukuran 4 pada tabel GLM-RM (General Linear Model Measure Repeat). Hasil pengukuran didapatkan setelah pemberian intervensi Model Transformational Service dengan pendekatan sistem interpersonal Imogene King di Puskesmas Tanjung Palas, bahwa 81,81\% artinya Model Transformational Service dengan pendekatan sistem interpersonal Imogene King efektif meningkatkan mutu pelayanan kesehatan di Puskesmas Tanjung Palas Kabupaten Bulungan.

Peneliti menilai bahwa mutu pelayanan kesehatan yang diberikan kepada pasien sebagai pelanggan dipengaruhi oleh sebuah perilaku yang dapat diamati dan ditemukan dalam sistem kesehatan di masyarakat. Dimana tujuan keperawatan adalah untuk membantu individu menjaga kesehatan mereka sehingga mereka dapat berfungsi dalam peran-peran mereka. Karena keperawatan adalah sebuah proses aksi, reaksi, dan transaksi interpersonal serta persepsi seorang perawat dan seorang pasien yang mempengaruhi proses sebuah pelayanan sesuai dengan sistem interpersonal Imogene King.

Dari penelitian Aisyah (2016) didapatkan bahwa perawat yang dimensi konteks kerjanya yang baik mempunyai peluang 2,121 kali akan menghasilkan mutu pelayanan yang baik juga. Hal ini menjawab apa yang tergambar pada perubahan kelompok intervensi dan kelompok kontrol pada pengukuran ke 4 dengan nilai mean pada kelompok intervensi 88,29 dan 83,44 pada kelompok kontrol .

Kualitas pelayanan kesehatan yang baik ditentukan oleh kompetensi dari perawat sebagai petugas kesehatan, tidak hanya dipengaruhi oleh tingkat pendidikan saja tapi juga dipengaruhi oleh perilaku Transformational service.

Peneliti berpendapat perubahan yang lebih baik pada sebuah organisasi/ pihak manajemen harus di rencanakan dengan tepat pada sebuah promosi dalam pelayanan yang diselaraskan dengan Visi dan Misi organisasi, tidak hanya memfokuskan pada pelaksanaan program saja tetapi juga penting untuk ditanamkannya prinsip-prinsip dalam pelayanan yang didukung oleh SOP, kebijakan dan dilanjutkan dengan motivasi untuk perubahan yang lebih baik secara terus menerus dan pemberian reward kepada staf.

Selain itu penting juga ditekankan dalam melakukan perencanaan. Perencanaan merupakan langkah awal sebelum kegiatan dilaksanakan yang meliputi kegiatan merumuskan tujuan puskesmas sampai dengan menetapkan kegiatan alternatif. Tanpa ada perencanaan puskesmas, tidak akan ada kejelasan kegiatan yang akan dilaksanakan oleh staf untuk mencapai tujuan puskesmas (Alamsyah,2011).

Menurut Bodek dalam Almalki, et al (2012) pegawai memiliki keinginan untuk dihormati atau dihargai atas pekerjaan yang dilakukan dan karakter diri mereka sendiri. Peneliti berpendapat hal ini lah yang menjadi latar belakang trend yang tergambar pada hasil di tabel GLM-RM (General Linear Model Measure Repeat ) . Jurnal Nerima (2011) menyatakan bahwa motivasi perawat secara signifikan lebih tinggi dari dokter dengan tingkat kepuasan kerja umum ( $p$ Value > 0,05). Dari informasi yang didapatkan bahwa kelompok kontrol sebelumnya pernah mendapatkan pelatihan tentang Standar Pelayanan Prima, hal ini pula yang dianggap sebagai 
salah satu penyebab kenaikan pada perubahan Mean dari pengukuran 1, 2, 3, dan 4 nya. Akan tetapi masalah ini bukan merupakan tujuan dari peneliti untuk membandingkan jenis pelatihan servis yang berbeda. Penelitian Rodwell ,et al (2008) menyimpulkan bahwa ada hubungan positif dan signifikan baik secara parsial maupun stimultan tehadap praktik komunikasi organisasional dengan kinerja karyawan. Peneliti berpendapat komunikasi organisasi yang baik telah disampaikan kelompok kontrol sehingga trend ini bisa terjadi. Penelitian Sulistyo (2009) juga menekankan terdapat pengaruh yang signifikan komunikasi organisasional terhadap kinerja karyawan. Fungsi komunikasi sebagai pengendali perilaku anggota organisasi dan saat organisasi menyampaikan keluhan terkait pelaksanaan tugasnya. Hal ini lah yang memperkecil kemungkinan terjadi proses pemecahan masalah yang produktif dalam interaksi antar individu dalam kelompok yang berbeda.

Sedangkan dari trend perubahan yang tergambar pada hasil di tabel GLMRM (General Linear Model Measure Repeat ) kelompok intervensi pada pengukuran 1,2,3 dan 4 juga didukung oleh faktor kepemimpinan. Dimana seorang pemimpin harus mampu memastikan bahwa bawahan melaksanakan pekerjaannya berdasarkan ketrampilan yang dimiliki dan komitmen terhadap pekerjaan untuk menghasilkan keluaran yang terbaik. Robbins menyatakan kepemimpinan merupakan kemampuan untuk mempengaruhi kelompok dalam mencapai tujuan yang dapat bersumber dari formal seperti posisi atau kedudukan dalam suatu organiasi. Menurut Kron yang diungkapkan pada penelitian Sri Aryanti (2017) bahwa kepemimpinan dalam manajemen keperawatan merupakan kemampuan dan ketrampilan seorang manajer keperawatan dalam mempengaruhi perawat lain dibawah pengawasannya untuk melaksanakan tugas dan tanggung jawab dalam memberikan pelayanan keperawatan sehingga tujuan keperawatan tercapai. Ditambahkan pula dengan pengorganisasian yang baik. Pengorganisasian merupakan serangkaian kegiatan manajemen untuk menghimpun semua sumber daya yang ada di Puskesmas dan dimanfaatkan secara efisien untuk program kesehatan. Selain itu diperlukan juga motivasi perawat seperti yang diungkapkan oleh penelitian Ria (2016) bahwa terdapat hubungan antara motivasi perawat dengan pelaksanaan asuhan keperawatan. Dimana mutu pelayanan diukur dari pelaksanaan asuhan keperawatan yang melibatkan sistem interpersonal pada perawat dan pasien. Desain pelayanan transformatif yang bertujuan untuk meningkatkan kesejahteraan layanan dan kesejahteraan entitas konsumen dengan berfokus kepada peningkatan hasil pelayanan kesehatan memang dibutuhkan agar memperoleh manfaat dari keterlibatan dan kolaboratif pasien maupun penyedia layanan, Sidney Anderson, et al (2017).

Pada hasil penelitian di pengukuran 1, 2, 3 dan 4 di kelompok intervensi dapat disimpulkan total nilai rata-rata yaitu 23,07\% Responsiveness (Daya tanggap) , $20 \%$ Assurance (jaminan) , 18,85 \% Tangibles (bukti fisik), 14,65 \% Emphaty (Empati), 15,62 $\%$ Realibility (kehandalan). Dari standar nilai kuisioner dengan jumlah total nilai 110 ,maka dapat dijelaskan bahwa hal yang perlu ditingkatkan pada kelompok 
intervensi yaitu Emphaty (Empati), dan Realibility (kehandalan).

Sedangkan pada kelompok kontrol di pengukuran 1,2,3, dan 4 dapat disimpulkan total nilai rata-rata yaitu 18,37\%Responsiveness (Daya tanggap), 17,6 \% Assurance (jaminan) , 14,7\% Tangibles (bukti fisik), 15,7 \% Emphaty (Empati), $\quad 16,37 \% \quad$ Realibility (kehandalan).

Asumsi peneliti bahwa ada beberapa hal yang perlu ditingkatkan dan ada yang dipertahankan pada kelompok kontrol dan intervensi.

Untuk dapat melaksanakan pembangunan kesehatan puskesmas perlu ditunjang oleh manajemen yang baik. Manajemen puskesmas adalah rangkaian kegiatan yang bekerja secara sistematis untuk menghasilkan luaran puskesmas yang efektif dan efisien (Kemenkes ,2012). Manajemen diselenggarakan sebagai proses pencapaian tujuan, menselaraskan tujuan organisasi dan tujuan pegawai puskesmas, mengelola dan memberdayakan sumber daya dalam rangka efisiensi dan efektifitas puskesmas, sebagai proses pengambilan keputusan dan pemecahan masalah, proses kerjasama dan kemitraan dalam pencapaian tujuan puskesmas (Alamsyah, 2011).

\section{KESIMPULAN DAN SARAN}

1. Model Transformational Service dengan pendekatan sistem interpersonal Imogene King dan pengaruh terhadap mutu pelayanan kesehatan di Puskesmas Tanjung Palas Kabupaten Bulungan Kalimantan Utara dapat dapat diketahui pengaruhnya .

2. Mutu pelayanan kesehatan di Puskesmas Tanjung Palas Kabupaten Bulungan Kalimantan Utara sebelum dan sesudah intervensi model
Transformational Service dengan Pendekatan sistem interpersonal Imogene King mengalami peningkatan pada pengukuran 1 dan pengukuran ke 4 dengan perbedaan nilai rata-rata yang signifikan

3. Mutu pelayanan kesehatan Puskesmas Bumi Rahayu Kabupaten Bulungan yang tidak menerapkan model Tranformational service dengan pendekatan sistem interpersonal Imogene King pada pengukuran 1 dan pengukuran 4 ternyata juga mengalami kenaikan dengan perbedaan nilai ratarata yang signifikan walaupun tidak setinggi nilai rata-rata pada kelompok intervensi.

4. Adanya perbedaan signifikan pada Mutu Pelayanan kesehatan setelah dilakukan intervensi Model Transformational Service dengan Pendekatan sistem interpersonal Imogene King pada Puskesmas Tanjung Palas Kabupaten Bulungan Kalimantan Utara pada pengukuran 1, 2, 3 dan 4 dapat disimpulkan bahwa $\mathrm{Ha}$ diterima.

\section{DAFTAR RUJUKAN}

Aisyah, (2016). Pengaruh Pelatihan terhadap Peningkatan Kemampuan Supervisi Ketua Tim dalam rangka peningkatan Kualitas Dokumentasi Asuhan Keperawatan Standar Akreditasi Rumah Sakit Versi 2012, Tesis tidak dipublikasikan, Universitas Muhammadiyah Jakarta.

Dian Yudhawati, Alimatus \& Reny, (2016). Pengaruh Pelatihan Kepemimpinan Transformasional Supervisor terhadap mutu pelayanan pramuniaga di Flora 
Grup, Universitas Mercu Buana, Yogyakarta.

Kemenkes (2012) Bentuk Pelayanan Puskesmas, Jakarta .

Muninjaya (2015).Manajemen Mutu Pelayanan

Kesehatan EGC,Jakarta

Ria Anugrahwati, (2016). Faktor-faktor yang berperan terhadap pelaksanaan asuhan keperawatan berdasarkan standar akreditasi Rumah Sakit Hermina Podomoro Jakarta, Tesis tidak dipublikasikan, Universitas Muhammadiyah Jakarta

Sri Ariyanti (2017). Hubungan Karakteristik Perawat dan Karakteristik Organisasi dengan Perilaku Caring perawat pelaksana di ruang rawat inap Rumah Sakit Tk II Kartika Husada Pontianak, Tesis tidak dipublikasikan, Universitas Muhammadiyah Jakarta.

Sidney Anderson,et al (2017), Transformative service research and service design: synergistic effect in healthcare, htttps://doi.org/.10.1080/02642069 .2017 .1404579 , di upload 11 agustus 201800.00

Widi Utami \& Ahmad Alim, (2012). Pengaruh Dimensi Kualitas Pelayanan Puskesmas S.Parman Banjarmasin Terhadap Kepuasan Pasien dalam memperoleh Pelayanan Kesehatan, Universitas Lambung Mangkurat. 